The $5^{\text {th }}$ International Conference on Family Business and Entrepreneurship

\title{
SOLVE DILEMMA OF CORPORATE SUSTAINABILITY: RESEARCH WITHIN INDONESIAN F\&B COMPANIES
}

\author{
Evelyn Indriani ${ }^{1 *}$, Eka Pria Anas $^{2}$ \\ ${ }^{1}$ Faculty of Ecomy and Business, University of Indonesia, \\ Corresponding author: evelyn.indrianil68@gmail.com
}

\begin{abstract}
Thrilled by changes in consumer behavior patterns and increased community awareness, Corporate Sustainability (CS) to minimize the environmental impact of business activities, is becoming an increasingly important discussion in Indonesia. However, CS is said to be resting on a dilemma between ethical obligations towards society versus economic duties of maximizing profits. As CS generates new stakeholder expectations towards the organization, company should take real action to solve dilemma. Research suggests that a company should have Strategic Communication (SC) that is built based on negotiation, understanding, and take into consideration "connections and responsibilities to a larger society" while launching CS. This SC will reinforce key proxy elements for successful CS and increased Corporate Performance (CP). Align with the Regulation of Indonesian Minister of Environment 75/2019, this research focused on the company's responsibility to manage plastic waste which includes reduction, collection, reuse, and recycling. The unit of analysis is $F \& B$ companies as one of the largest economic contributors in Indonesia but is also responsible for a variety of different environmental impacts. Quantitative data collection through online questionnaires processed with Partial Least Square (PLS) 3.0. The results show that even though company has made CS as one of the work programs, formed a division to handle CS, as well as awareness of changes in consumer behavior, they acknowledge the lack of SC. By proposing a set of conceptual principles that merge theory and practice, results expected to develop answers to the question: how best to communicate CS thereby contributing to the improvement of the CP?
\end{abstract}

Keywords: strategic communication, corporate sustainability, plastic waste, corporate performance, food and beverage companies

\section{Introduction}

The Corporate Sustainability, in this study abbreviated as CS, involves the two subjects of corporate and environment, which is different from the two sides of corporate and stakeholders in the overall scope of Corporate Social Responsibility (CSR) (Shahzad et al.,2020). According to Kantabutra, S. (2020), CS inquire leadership and management approach to brings social, environmental, and economic outputs. As company launch CS to meet the needs of the present without compromising future needs, it's also holds an opportunity and competitive advantage (Kramer, 2006). Elkington (1994) termed definition of sustainability as "the triple bottom line" (TBL) of people, planet, and profit. TBL underlines the necessity of balancing social, environmental, and economic outputs and further considered as the main proxy to measure sustainability performance (Fauzi et al., 2010; Lacy et al., 2010; Berns et al., 2009). In Indonesia, 
CS becoming an increasingly important discussion, especially after few research highlights local improper waste management and ranked Indonesia as the world's second-worst marine plastic polluter (Jambeck, 2015). This raises a tipping point where a group of people with ideas, products, news and behavior for environmental sustainability spread very quickly and contagious like a virus, and unknown transformed into something really big (Gladwell, 2000). Few public surveys administered within 2020 and 2021 show consumers behavior changes. 55\% recognize that it's a strategic role of corporations to reduce the volume of plastic waste (Alliance of Zero Waste Indonesia, 2020); prefer to purchase from a company with responsibility programs (McKinsey, 2020); and 62\% acknowledge increased urgency to address climate change and environmental matters (Edelman Trust Barometer, 2021). These surveys suggest business to know what they are stand for, communicate their sustainability narrative, and reinforce sustainability identity in every interaction with their customers.

Few studies have confirmed CS significant impact on financial performance when communicated strategically to increase sustainable growth rate and ROE (Kuo and Chang, 2021); and contribute largest synergistic effect on Tobin's $Q$ as one of strong indicator for company's attractiveness of investment (Kwon and Lee, 2019). Amidst changes in consumers behavior and contribution to corporate performance, significant cost increment and undefined long-term consequences of CS provide a weak justification and failure in recognize the importance of CS in company strategies. Company may not fully enjoy the benefits of CS because they don't use a value-based approach (Chandler, 2014), has not strategically linked it to the core business (Beth and Ruggie, 2005), and does not build Strategic Communication, in this study abbreviated as SC, to anticipate the needs of stakeholders in their business environment, so that they can only see how important this program once important cases arise that attack their business (Kaplan, 2020). While theoretically CS could role as differentiation strategy so firm can achieve sustainable competitive advantage, with lack of stakeholders' support and awareness, this potential might could not be happened. Plastic waste issue in Indonesia is not solely the responsibility of company, instead it's the stakeholders, including consumers, media, suppliers, and government. However, due to lack of communication and coordination, the visible impacts have not been recognized. Referring data from the Global Plastic Action Partnership (GPAP), amidst government various program on Waste Bank and waste sorting (TPS 3R) launched in the past nine years, from annual 4.8 million tons of plastic waste, $48 \%$ still being openly burned, $13 \%$ dumped on land or in poorly managed dumpsites, and leaking into waterways and the ocean (9\%). Responding this critical issue, Government officially launches national target for $70 \%$ waste reduction by 2025 and translate the concrete steps in the Regulation of the Minister of Environment and Forestry number 75, year 2019.

The rationale behind focusing this CS research on Indonesia in particular, is three-fold. First, developing countries represent $85.1 \%$ of the world's population and account for $48.9 \%$ of the world's GDP (IMF, 2012, p. 179). Second, many key studies highlight Indonesia as one of major world's waste producer created pushing effort to government to release supporting regulation and monitoring. Third, the purpose, practices, and priorities of CS in developing countries are quite different from those in developed countries due to different political systems, regulatory frameworks, socio-economic priorities, stakeholder demands, and cultural context. In their comparative study, Chapple and Moon (2005) investigate the CS practices of 50 organizations operating across seven Asian countries that include Indonesia and find that environment conservation was one of the most important issue. That's why we would like to locate the contribution of this study to encourage $\mathrm{F} \& \mathrm{~B}$ companies in Indonesia to build up SC for their CS to reap the positive impacts to Corporate Performance; to extend theorizing on conceptual CS strategic management research in Indonesia F\&B industry; and to provide relevant information for regulators in formulating policy that support CS implementation. The attitude of the government and the public towards CS may be the driving force for Indonesia F\&B companies to move towards green and environmental protection.

While less research has engaged with the management of CS dilemma, our quantitative study will focus on SC to mediate CS translates into TBL to increased Corporate Performance, in this study abbreviated as CP. For TBL, social output will bear dimension of corporate social capital, environmental output from dimension of green product innovation, and economic output from dimension of cost control. It is 
undeniable that the obligation to comply with regulations on plastic waste management will be even stronger, coupled with community groups and NGOs actively demanding companies to be responsible for the environment and for the waste they produce. To try to solve the dilemma above, this research aimed to better understand the interrelationships between company's strategy in communicating CS to increased Corporate Performance. Thus, main question for this quantitative research is: How Strategic Communication of Corporate Sustainability can lead company to achieve Increased Corporate Performance? Independent Variable is Corporate Sustainability (CS) on Plastic Waste. Mediating Variable is Strategic Communication (CS). Dependent Variable is Corporate Performance (CP). Based on forementioned research objectives, questions, and variables, we illustrate research model in Figure 1.1.

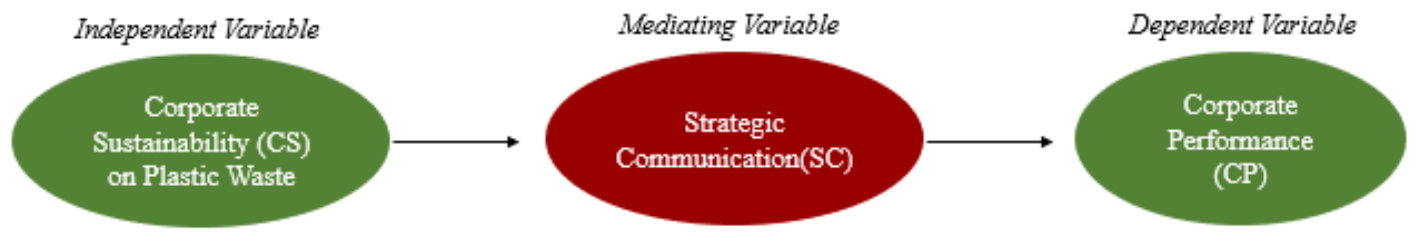

Figure 1. Research model

\section{Literature Review}

\section{Corporate performance}

Earlier study found CS as a strategic tool for products differentiation, stakeholder relationship, reputation management, market penetration, and achieving competitive advantage (Carroll, 1979, 1991; Schaltegger and Burritt, 2010; Hoejmose et al., 2013; McWilliams, Siegel, \& Wright, 2006; McWilliams and Siegel, 2001). This is because TBL as integration of main proxy of CS, create difficult-to-imitate combinations of firms' resources to provide competitive advantage (Griffith and Harvey, 2001 in Zhang, 2014). However, due to market complexity and interdependencies of all stakeholders, company should organize Strategic Communication (SC) to actively engage stakeholders, for instance support to purchase from businesses that actively employ sustainable business practices, and to recommend them. Backed by previously described customers behavior changes and importance of sustainability identity, Corporate Performance, in this study will be mainly discussed from the area of 1)Customer's Preference for repurchase intention and loyalty behavior; and 2)Brand Equity to strengthen corporate reputation as a critical factor in maintaining a competitive advantage in today's global market and a strategic indicator of increases in a firm's value (Flammer, 2012; Love and Kraatz, 2017; McGuire et al., 1988).

Customer loyalty is intention to repurchase the products and services and referrals to others. CS influence and stimulate the positive relationship between the customer and the company and its products and services (Uhlig, et al., 2020). This loyalty results in a customer's preference to buy and support a particular company's products despite any marketing efforts of companies and brands. The relationship between CS and customer loyalty is explained through the theory of social exchange, that's if a firm involves socially responsible behavior, then this creates generalized reciprocity (Blau, 1964). Customers, guided by their ethical and moral values, are also concerned to make this world a better place. Customers show affinity, trust, and a strong bond with companies exhibit environmental responsibility in the processes. Becchetti et al. (2020) evaluate the role of communication on customers preference over regular product and product from company demonstrate commitment on CS. Results shows even though responsible product costs more, the percentage of consumers increased from 37.5 to 41.7 , and then to 45.3 concomitant with SC that worked under conformism design.

Brand equity defined as a set of assets associated with a brand, its name and symbol, which increase or decrease the value provided by a product or service to customers (Aaker, 1997:23). There are three main components that make up brand equity according to Kottler (2002:268): 1) brand identity such as a logo or name; 2) products, services, and accompanying marketing activities; and 3) other associations provided by linking the brand with other activities such as innovations, values, or programs. 
As one of the most competitive intangible factors in a corporation's social value and image, brand equity is a critical factor in maintaining a competitive advantage and support long-run business performance in today's global market. Brand equity provides value to customers by strengthening interpretation, information processing, purchasing confidence, and achieving satisfaction. While for the company, brand equity provides value by strengthening program efficiency and effectiveness, brand loyalty, brand extension, and competitive advantage (Aaker 1997:23). Study by Rahman et al. (2019) demonstrates that firms using CS as an instrument to enhance their relationship with their stakeholders derive additional benefit in the form of higher market share and strong brand equity which will assist them in achieving a competitive advantage in the marketplace and affecting performance. Brand equity is determined by the information communicated to consumers, and how this is received to fostering trust. Environmental dynamic such as changes in customer preference, changes to demographics and social values, government regulations, and technology adoption, plays a massive role for an organization (Ge, et.al., 2019). Greater market transparency and new business opportunities, which arise from the customer's preference and brand equity of the committed firms, may be crucial in fostering the purchase of their products and supporting company, not only in current time, but also forward-looking (Becchetti et al., 2020). Since TBL as an output of CS accommodate social relationship, products innovation, and efficiency, researcher hypothesize that CS is one of the unique things that distinguishes a product or company from others in the market, generates preference and brand equity. This leads to our first hypothesis. H1: Corporate Performance (CP) is positively associated with the adoption of Corporate Sustainability (CS).

\section{Antecedents and outputs of Corporate Sustainability (CS)}

Prior to discuss on proxy to measure CS performance, we will briefly introduce two antecedents for successful CS to give better connection on how SC later can be integrated. First antecedent is competence fit which leverage company's creative capabilities in manipulate their resource bases into new productive configurations of competencies in dynamic environments (Eisenhardt and Martin, 2000; Galunic and Eisenhardt, 2001; Grant, 1996; Pisano, 1994 in Zhang, 2014). Second antecedent is culture fit defined as a social control system based on shared norms and values that set expectations about appropriate attitudes and behavior for members of the group (O'Reilly \& Chatman, 1996, p. 160). CS requires organizations to undergo significant cultural change and transformation. That's why an appropriate organizational culture is essential for CS integration to company's differentiation strategies (McWilliams et al., 2006). Once team perceive their organizations as having an ethical on environment, they are more likely to be committed and motivated to support company efforts in CS and create greater trust and mutual dependence. Uphadaya et al. (2018) found that the association between differentiation strategy and the adoption of CS is fully mediated by the innovation dimension of organizational culture.

The main proxy to measure CS defined as Triple Bottom Line (TBL). As elaborated in our research model, social output represents by stakeholder engagement in the frame of Corporate Social Capital, environmental output linked with Green Product Innovation (GPI) as products development with efficiency usage of materials and energy (Dangelico, 2016; Noci and Verganti, 1999; Zhu et al., 2008), and proxy of economic associated with cost control through improved productivity and lower operating costs. Corporate Social Capital (CSC) is the sum of the resources, actual or virtual, that accrue to an individual or a group by possessing a durable network of institutionalized relationships of mutual acquaintance and recognition. CSC includes any means of business leverage, embedded in social relations, thus assisting a firm in promoting internal assets and resources (Leenders and Gabbay, 1999, p.106). If CSC are not properly maintained, to the degree that the corporate social structure producing CSC is rigid, they tend to fade out or turn into a corporate liability. We linked CSC into RBV approach whereas if company resources are valuable, rare, immobile, and non-substitutable (VRIN), they can be a source of competitive advantage (Barney, 1991). CS supports the attributes of CSC which even though they are bearing investment cost, they are relation-specific and cannot easily be transformed from network-to-network. Georg Simmel (1955), a theorist of sociology's classical period, identify within certain forms of conflict entailing the internal social control, company can build an intrinsically ordered interweaving of relations based on 'the 
possibilities of gaining favor and connection'. Active CS performance is conducive to develop relations with stakeholders (Horisch et al., 2014).

Green Product Innovation (GPI) defined as new product development practices that "reduce the negative impacts and risks to the environment, utilize less resources and prevent waste generation," thereby resulting in products that provide "environmental benefits higher than conventional products" (Lin et al., 2013, p. 103). Liu et al. (2021) verify that CS effectively promote technological innovation performance at a certain critical threshold. However, as Schumpeter said, innovation is about reinventing business processes and building entirely new markets that meet untapped customer demand (Teece, 2009). CS support organization differentiation strategy by integrate social and environmental attributes in their products (product innovation) and produce them in a socially responsible manner (process innovation). Given the importance of CS to improve innovation performance (Bocquet et al., 2013), CS should be regarded as the management strategies, rather than a burden.

According to Fisher (2010), CS is important to organizations not only because firms have a social responsibility to the environment and to future generations; but also because CS direct company to efficiency, which ultimately leading to higher profits and a better image for the organization. Horngren in Horngren, Datar, Rajan (2011) convey two important elements of cost control. First is waste reduction which show how well resources should be used during the production processes, and also encourages employees to find ways to improve efficiency. Second is Operational Efficiency (OE) that indicate firm's operational excellence to transform various resources into value-added outputs (Amess and Girma, 2009). $\mathrm{OE}$ involves regular routines for better performance, and efficiency-driven best practice for sounds organizational processes and operations (Krasnikov and Jayachandran, 2008).

\section{Strategic Communication (SC)}

Cited from wikipedia.com, Strategic Communication (SC) is the systematic planning and realization of information flow, communication, media development and image care in a long-term horizon. It conveys deliberate message through the most suitable media to the designated audience at the appropriate time to contribute to and achieve the desired long-term effect. Few significant organizational drivers for SC, include the chairman's favourable attitude towards CS, internal champions (Busco et al., 2018; Contrafatto, 2014), material, and symbolic sensitivity to the emerging sustainability logic (Bouten and Everaert, 2015). SC involves implicit and explicit communication. Implicit communication embedded in cultural, values, word-of-mouth communication, organizational practices, and norms. Explicit communication expressed in brand campaigns, advertising, webpages, vision statement, and CSR reporting. To manage implicit and explicit SC, researcher refer to three disciplining cycle asserted by Morsing and Spence (2019). Surveillance enables changes and mobilize company to perform according to stakeholders' expectations. Examination involves documentation elaboration, where CS results are recorded, reported, and analyzed. Normalization is how norms are imposed so it seen to be appropriate and represent what is right in society (Crane et.al., 2008).

While we recognize the importance, unfortunately a shared view on the role of SC may be less evident. This may stem from a scant understanding on the CS relevancy to the business, whether and how it could add value. Communicating CS also needs to be carefully considered as consumers often question the meaningfulness of CSR initiatives (Hess and Warren, 2008; McWilliams and Siegel, 2011). This skepticism can easily backfire and caused long-term damaging consequences for the firm (Nyilasy et.al., 2013). SC of CS can establish a strong corporate image and reputation when stakeholders believe the company is committed to being a good corporate citizen (Stanaland et al., 2011). A central aspect of Strategic Communication (SC) on Corporate Sustainability (CS) then should moderate by information transparency (Kim, 2017; Wu et al., 2020); alignment of communication and action; and allow environmental disclosure. Besides "inside-out" approach whereas company report the CS performance to the public, SC should also activate "outside-in" approach to reducing information asymmetry between company and its stakeholders. According to Teece (2009: p.35), effectively communicating by recognizing values and culture is one of strategic decision skills for execution. Align with findings from that capitalization of CS practices that 
supported by SC contribute positively for firm valuation (Fan et al., 2020); enhance the strategic positioning and competitiveness (Kantabutra, 2020); and increased customers loyalty and preference (Becchetti et al., 2020), we thus propose the second hypothesis. H2: The Strategic Communication is likely to mediate the association between Corporate Performance and the adoption of Corporate Sustainability.

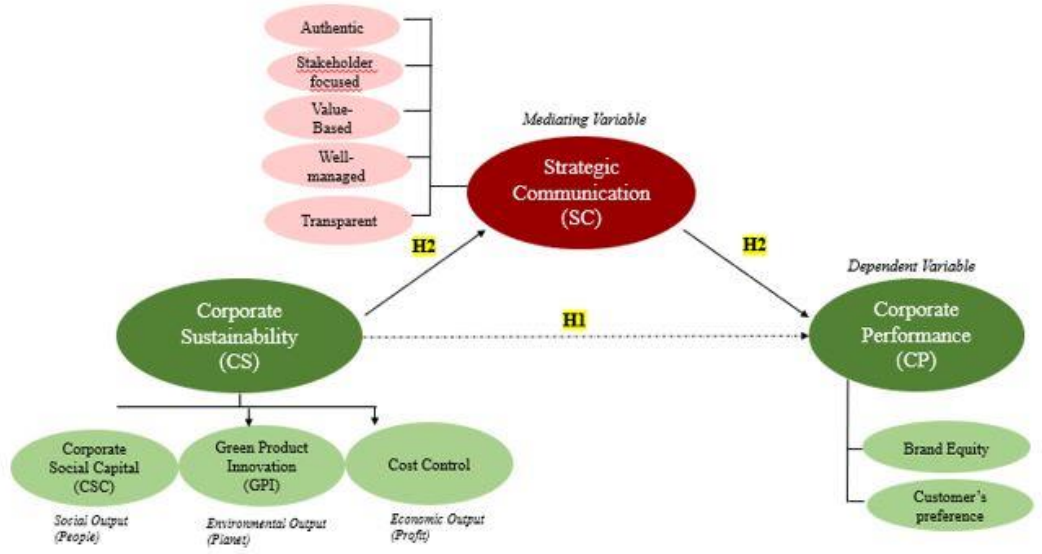

Figure 2. Conceptual model

\section{Research Method}

Plastic waste can be generated from the production or manufacturing process, services such as restaurants or hotels, and retail such as shopping centers and markets. Considering that eating and drinking is a primary need that dominates our lives, the F\&B industry is one of the largest economy contributors but is also the largest waste contributors up to 75\% to landfills (Greenpeace Indonesia, 2019). This is what makes research on CS plastic waste in the F\&B industry is relevant. The F\&B industry is also one that has high dynamics of innovation and communication, and its value chain involves multiple stakeholders. Research collects quantitative data on the $\mathrm{F} \& \mathrm{~B}$ companies engaged in manufacturing, services, and retail, with support from the Industry Association. Companies join Industry Associations for advocacy, regulation, and collaboration opportunity. By collecting data from specific associations, researchers not only gain insights in the form of data, but also distribute research results to support objectives, including to encourage company to reinforce CS identity and communication in every interaction with their customers, and building CS collaboration that accelerates environmental improvement. This research was using an online questionnaire for primary data collection, employed explanatory research to highlights the causal relationship between research variables, and Partial Least Square (PLS) 3.0. for data processing and test the formulated hypotheses. The SmartPLS method with bootstrapping technique was chosen because with the amount of data $<100$, the relationship between variables in the outer model is reflexive or based on theories or indicators that have been used by previous researchers. In this step, a SEM model diagram is developed which aims to make it easier to see the tested causal relationships. There are two research hypotheses proposed. H1: Corporate Performance (CP) is positively associated with the adoption of Corporate Sustainability (CS). H2: The Strategic Communication is likely to mediate the association between Corporate Performance and the adoption of Corporate Sustainability.

Respondents were asked to indicate on a five-point Likert type scale ranging from 1 'not at all' to 5 'to a great extent' to illustrate their preferential on the described statement or condition, while still provides independence to a participant to choose any response in a balanced way (Joshi and Pal, 2015). Research managed to collect 88 respondents from management and employees, age ranges 24-60 years old and currently working within F\&B industry in Indonesia. Reasoning to define the age ranges is by considering the criteria of the productive group in Minister of Manpower Regulation number 02, year 1995. Further, Presidential Regulation number 59, year 2017, concerning Indonesia's sustainable development, invite all parties, particularly the productive group, to actively participate in achieving the SDGs in Indonesia. 
However, the younger generation had relatively higher pro-sustainable attitudes and willing to dispense income to work for SDG-minded companies (Yamane and Kaneko, 2021).

This study applies five control variables: type of company, period of operations, size of company, industry type, and institutional ownership. Type of organization was measured by whether the company was local/domestic or a multinational company. Domestic company operates only in one country, while multinational company operates in more than one country. Cowan (2020) found a higher CS tendency for multinational company during his research to to 135 brands from various industries and countries. Period of operations measured by period of establishment. Size of company measured by a number of employees. Institutional ownership was measured by whether the company was listed on the Indonesia Stock Exchange or was a non-listed company at the time of data collection. Period of operations measured for the consideration of this can be a sign of organizational inertia (Beer and Nohria, 2000). As CS defined as a source of opportunity and competitive advantage, absence of CS and its communication can be a sign of an organizational inertia. According to GRI's Sustainability Disclosure Database in 2018, only 10-15\% sustainability reports came from SMEs, even though it can bring a variety of positive benefits, including attracting investors to inject their funds and becoming a reference for the state of their business. Reasons for low reporting or communication on CS are lack of awareness of business owners of the benefits of CS, lack of information on how to implement CS, and the interference of intended CS initiatives with other business initiatives. That's why we also include size of company and institutional ownership as control variable in this study. For type of industry, we align to definition of producer in Regulation Minister of Environment 75/2019, which consists of manufacturing, services, and retail.

\section{Results and Discussion}

Before we discuss the findings from the survey, we evaluate measurement model to assess the validity and reliability of the model. The outer model shows the specification of the relationship between the estimated indicator and its latent variable (measurement model). From Convergent Validity Testing, all indicators have outer loading $>0.5$ hence it is valid.

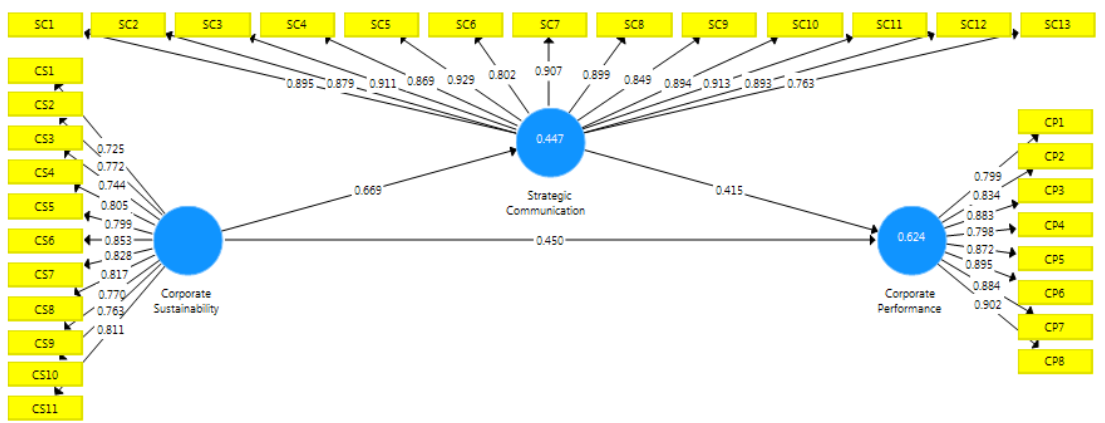

Figure 3. Evaluation of the outer model

Further, in order to check degree of conformity of the measurement results of a measuring instrument with what should actually be measured, we imply Average Variance Extracted (AVE) testing. The acceptable AVE value must be greater than 0.5 . Validity refers to how accurately a method measures what it purports to measure. AVE value for $\mathrm{CS}=0.625$; $\mathrm{SC}=0.772>0.5$, and $\mathrm{CP} 0.738$. It means all of them are valid and the indicators used are the right indicators. To measure the level of reliability, we use Cronbach alpha. The purpose of testing is to ensure that the instrument used produces the same output when testing the concept with different indicators. If the Cronbach alpha value is below 0.70, it can be said that the measurement instrument does not have good consistency (Malhotra, 2015). So, reliability implies stability (not changing), consistency (steady), and dependability (reliable). Composite reliability for CS $=0.948 ; \mathrm{SC}=0.978$; and $\mathrm{CP}=0.957$. Cronbach alpha for $\mathrm{CS}=0.940 ; \mathrm{SC}=0.975$; and $\mathrm{CP}=0.949$. 
Below we discuss our findings related to initial research question if SC on CS can lead company to achieve increased CP. From the online survey conducted within October 2021, which the distribution was helped by Indonesian Food and Beverages Association (GAPMMI) and Indonesian Shopping Center Tenants Association (HIPPINDO), we managed to get 88 responses. $71 \%$ of our respondents are from age ranges 24-30 and 31-40 years old, worked in private manufacturing companies with period of establishment $>20$ years and employed $>1000$ people. As for type of company, proportion of domestic and MNC looks balanced. Respondents mostly answered that their company has a division or employee who specifically handles waste management; plastic waste management has elaborated in the company's goals and work programs; and that their company recognize importance of consumer behavior trends related to plastic waste. However, respondents found lack of real initiatives or plan from company to produce product packaging made from recycled materials. This might be because low supports from supplier and also low customers awareness shown by purchase preference to support the company's recycling program. Awareness may have been awakened, but there are obstacles such as the reluctance of consumers to pay more for products that implement sustainability. Things like this are included in the dilemma faced by the company related to desire for sustainable consumption and actual unsustainable consumption behavior (Hahn, et al., 2015) reflected in consumer's unwillingness to pay surplus for sustainable consumption, insufficient quality or access to such products/services, unawareness of detrimental impact, or fact that CS is differently understood in different cultures and also organization. Because of that, CS should strategically communicate internally to build management dialogue, externally to build stakeholder dialogues, and collaborated in roundtables with other organization, for example with the Indonesian Consumers Foundation (YLKI). Regular and structured communication campaigns also needed, by always imply methodical manner according to the needs of the audience. This is because respondents also highlight company communication about plastic waste management that has not used language and methods that are easy for customers to understand.

Table 1. Respondents' analysis

\begin{tabular}{lll}
\hline Criteria & Most answers & Percentage \\
\hline Age range & $31-40$ years old & $38 \%$ \\
& $24-30$ years old & $33 \%$ \\
& $41-50$ years old & $26 \%$ \\
Institutional ownership & Private & $87.5 \%$ \\
& Public & $12.5 \%$ \\
Field of company & Manufacturing & $63.6 \%$ \\
& Services & $21.6 \%$ \\
Type of company & Retail & $14.8 \%$ \\
& Domestic & $52.3 \%$ \\
Period of company & Multinational (MNC) & $47.7 \%$ \\
& $>20$ years & $47 \%$ \\
\multirow{5}{*}{ Number of employees } & 6-10 years & $26 \%$ \\
& $11-15$ years & $17 \%$ \\
& $>1000$ people & $51 \%$ \\
& $>500$ people & $18 \%$ \\
& $200-500$ people & $14 \%$ \\
\hline
\end{tabular}


Table 2. Indicators' analysis

\begin{tabular}{|c|c|c|c|}
\hline Variables & Mean & Indicator & Questionnaire \\
\hline \multirow[t]{3}{*}{$\begin{array}{l}\text { Corporate } \\
\text { Sustainabilility }\end{array}$} & Highest & CS1 & $\begin{array}{l}\text { The company has a division or employee who } \\
\text { specifically handles waste management }\end{array}$ \\
\hline & Lowest & CS5 & $\begin{array}{l}\text { Supplier supports the company's plastic waste } \\
\text { processing program }\end{array}$ \\
\hline & & CS8 & $\begin{array}{l}\text { The company has/will produce product packaging } \\
\text { made from recycled materials }\end{array}$ \\
\hline \multirow[t]{3}{*}{$\begin{array}{l}\text { Strategic } \\
\text { Communication }\end{array}$} & Highest & $\mathrm{SC} 1$ & $\begin{array}{l}\text { Plastic waste management is one of the } \\
\text { Company's goals and work programs }\end{array}$ \\
\hline & Lowest & SC11 & $\begin{array}{l}\text { The company's communication about plastic } \\
\text { waste management uses language and method that } \\
\text { are easy for customers to understand }\end{array}$ \\
\hline & Highest & CP1 & $\begin{array}{l}\text { The company recognize importance of customer } \\
\text { behavior trends related to plastic waste }\end{array}$ \\
\hline $\begin{array}{l}\text { Corporate } \\
\text { Performance }\end{array}$ & Lowest & $\mathrm{CP} 2$ & $\begin{array}{l}\text { Customers buy products because they want to } \\
\text { support the company's recycling program }\end{array}$ \\
\hline
\end{tabular}

To test the structural models, relations, and hypothesis, we examine the inner model which describe the relationship between latent variables based on substantive theory. The structural model was evaluated using R-square for the dependent construct, and Stone-Geiser Q-square test for the relevant predictive (Haryono, 2017). The value of $\mathrm{R} 2$ can be used to assess the effect of certain independent latent variables, whether the dependent latent variable has a substantive effect. The higher the value of $\mathrm{R} 2$ the greater the ability of the independent latent variable to explain the dependent latent variable. R2 value for $\mathrm{SC}=0.447$ and $\mathrm{R} 2$ value for $\mathrm{CP}=0.624$ which means that it is included in the moderate category. So it can be concluded that CS has a considerable impact on SC, then CS and SC have a significant impact on CP.

Q-square measures how well the observed values are generated by the model as well as the estimated parameters. The magnitude of $\mathrm{Q} 2$ has a value range of $0<\mathrm{Q} 2<1$, where the closer to 1 means the better the model. The quantity of Q2 is equivalent to the coefficient of total determination in path analysis. The value of Q2> 0 indicates that the model has predictive relevance, otherwise if the value of Q2 $\leq 0$ indicates that the model lacks predictive relevance. Q-square value from this study $=0.792$, shows that the amount of diversity of research data that can be explained from this study is $79.2 \%$ and the remaining $20.8 \%$ is explained by other factors outside this study.

In PLS, each relationship is tested by using a simulation using the bootstrapping method on the sample. This test aims to minimize the problem of abnormality in the study. Testing the research hypothesis using the t-statistic coefficient. Where the output of the bootstrapping command produces t-statistics. Indicators that have a t-statistic $>1.96$ are said to be significant. An indicator can also be said to be influential if it has a p-value $<0.05$.

Table 3. H1 testing (direct influence)

\begin{tabular}{cccccc}
\hline H1 & $\begin{array}{c}\text { Original } \\
\text { sample }\end{array}$ & Sample Mean & Standard Deviation & T statistics & P value \\
\hline CS to CP & 0.450 & 0.452 & 0.098 & 4.576 & 0.000 \\
\hline
\end{tabular}

From the results of testing the direct influence hypothesis, it can be concluded that the influence of CS on $\mathrm{CP}$ has a t-statistic value of $4.576>1.96$, p-value $0.000<0.05$ and original sample path coefficient value $=$ 0.450 then $\mathrm{H} 1$ is accepted, meaning that $\mathrm{CS}$ has a positive and significant effect on $\mathrm{CP}$. Changes in the value of CS have a direct effect on changes in $\mathrm{CP}$, or in other words if CS increases, there will be an increase in the level of CP and statistics show a significant effect. The path coefficient describes the influence between variables, a high result describes a greater influence (Ghozali and Latan, 2015). 
Table 4. H2 testing (indirect influence)

\begin{tabular}{cccccc}
\hline H2 & $\begin{array}{c}\text { Original } \\
\text { sample }\end{array}$ & Sample Mean & Standard Deviation & T statistics & P value \\
\hline $\begin{array}{c}\text { CS to SC to } \\
\text { CP }\end{array}$ & 0.278 & 0.275 & 0.087 & 3.202 & 0.001 \\
\hline
\end{tabular}

Further, we test second hypothesis, results show the influence of CS on CP through SC has a t-statistic value of $3.202>1.96$, p-value $0.001<0.05$ and path coefficient value $=0.278$. It is confirmed to accept $\mathrm{H} 2$ meaning that CS contribute positive and significant effect on $\mathrm{CP}$ with $\mathrm{SC}$ as a mediating variable. It means that changes in the value of SC have a unidirectional effect on changes in the influence of CS on CP. Likely if SC increases, then there will be an increase in the level of influence between CS on CP, and statistically the effect is significant. From evaluation of outer and inner model, our testing confirmed H1: Corporate Performance (CP) is positively associated with the adoption of Corporate Sustainability (CS) and H2: The Strategic Communication mediate the association between Corporate Performance and the adoption of Corporate Sustainability.

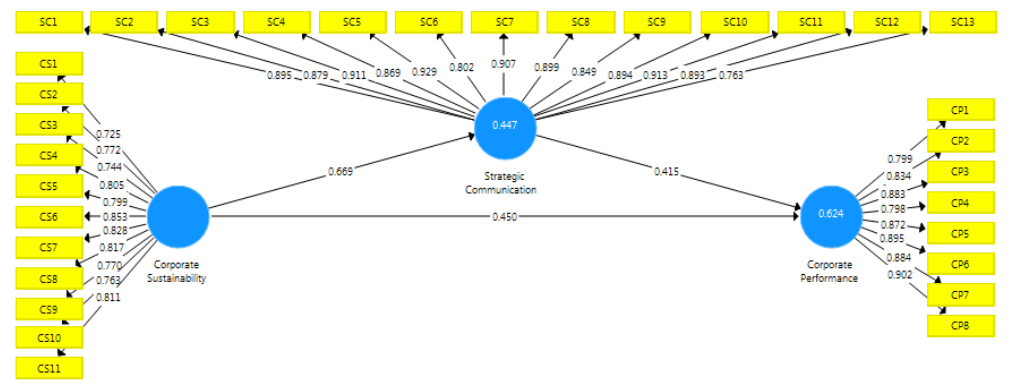

Figure 4. Evaluation of the inner model

Our research findings add more insights to study Teixeira (2019) which elaborate CS into Business Organizational Management to achieve increased performance, partnership, and motivation. Teixeira showed importance of CS priority promoted by top management. Our study adds up by emphasize how top management could step beyond employs division to handle CS, but also strategically communicate with suppliers and with consumers to support their CS. Later, if we check integrated CS model developed by Kantabutra (2020), company can communicate not only their sustainability vision and values which is considered as one-way message, but also SC with focus on stakeholders. Interestingly, in our study, company have recognized importance of consumer behaviour trends related to plastic waste. So, next company could consider SC with value-based, authenticity, and focused to consumers' needs and actions, such as to make consumer feel as a part of company CS journey, explore various effective communication channels, language, and methods.

\section{Conclusion and Implications}

Our study confirmed that SC mediating association between CS and CP, with few important practical findings that company suggested to communicate plastic waste management through brand campaigns, advertisements, web pages, or official activity reports with language and methods oriented to customer needs and conditions. Further, survey also shows that with SC, employees committed to support the company's program in plastic waste management and are motivated to play a role in reducing plastic waste. Our research contributes to showing how SC can be an approach to mediate interest, share, or claim that a group or individual has in the outcome of a CS toward others, and then this study also tested that if company 
raise its efforts on CS and $\mathrm{SC}$, it will increase the $\mathrm{CP}$, on the context of customers preference and brand equity.

By analyze our respondents, who mostly worked in large manufacturing F\&B firms, looked balance between public and private; and also, indicators developed from SC, CS, and CP literature, we understand few positive trends. First, company has a division to handles waste management, and second, company is committed to complying with government regulations regarding the management of plastic waste. On the other hand, even though companies not yet or plan to manufacture packaging from fully recycled plastic materials, the company has start packaging innovations to reduce plastic waste. This recycling constraint may lie in the low awareness sorting, collection and recycling among customers and stakeholders.

On the other hand, our study also find that customers have not shown high purchase preference to support the company's recycling program, and supplier need to increase their support in technology and materials. Because of that, given the breadth and complexity of the things that must be done, from upstream to downstream, the success of CS efforts is only possible with the concept of Extended Stakeholder Responsibility (ESR), rather of Extended Producers Responsibility (EPR). Stakeholders consists of primary and secondary stakeholders (Sims, 2003). Primary stakeholders own direct stake in the organization, including shareholders, BOD, owners/investors, customers, employees and managers, local communities, suppliers, and other business partners. Secondary Stakeholders is representational of public or those with special interests such as media, government and regulators, environmental groups, civic institutions, and trade associations.

With the $70 \%$ national target waste reduction by 2025 , government regulation, and a tipping point from stakeholders to demand company responsibility on environment sustainability, Strategic Communication enable company to anticipate the needs of stakeholders in their business environment (Kaplan, 2020). For instance, few F\&B companies initiate Indonesia Packaging Recovery Organization (IPRO) in 2020. From the essence of dynamic capabilities, this shows how company expertly and collaboratively where the situation allows and requires (Teece, 2009). By joining forces, they can build Strategic Communication by initiate advocacy to the government more effectively, engage suppliers for raw materials and recycling processes, educate customers by engaging in marketing and labelling programs, and attract media attention. Furthermore, the multi stakeholders' collaboration, from Indonesia's leading policymakers, finance institutions, experts, businesses, entrepreneurs, to civil society organizations, also started in National Plastic Action Partnership (NPAP). This stakeholder collaboration needs to support by Strategic Communication to ensure that the message of importance of CS can be delivered to all external stakeholders and encourage all members to align it with their action to ignite trust and engagement.

The results of this study are expected to provide two important implications. First, the company realized that this was the right moment to do CS and not to waste the opportunity to achieve business growth by communicating its CS. Communication steps are facilitated by changes in consumer behavior as well as the breadth of communication channels and methods that can be utilized. Second, all stakeholders include company recognize the need to communicate together and collaborate to realize this CS. Because by supporting each other and communicating it, they can build a broader, stable, growing, and sustainable CS. Given this study objectives to propose an integrated theory of CS and SC, there are few limitations needed to be addressed by future research. If $F \& B$ is an industry that is directly related to consumers (B2C), the research can also be extended to the B2B industrial sector such as agriculture and mining, or other B2C sectors such as personal care and textiles. Hence, future research has to continue to validate and refine our proposed findings, possibly with more examples of corporations from a variety of different contexts. And in our present study, we include brand equity and customers preference to link it to CS. Future studies may want to include the other intangible values to measure corporate performance, such as reputational capital and market resilience. 
References

Albats, E., Alexander, A., Mahdad, M., Miller, K., \& Post, G. (2020). Stakeholder Management In SME Open Innovation: Interdependences And Strategic Actions. Journal of Business Research, Vol.119. 291-301.

Andersen, J. (2021). A Relational Natural-Resource-Based View On Product Innovation: The Influence Of Green Product Innovation And Green Suppliers On Differentiation Advantage In Small Manufacturing Firms. Technovation., https://doi.org/10.1016/j.technovation.2021.102254

Apostol, O., Makela, M., Heikkila, K., Hoyssa, M., Kalliomaki, H., Jokinen, L., \& Saarni, J. (2020). Triggering Sustainability Communication In A B2B Context Combining Action Research And Sensemaking. Accounting, Auditing \& Accountability Journal. https://doi.org/10.1108/AAAJ-082019-4125

Becchetti, L., Corrado, G., Pelligra, V., \& Rossetti, F. (2020). Satisfaction And Preferences In A Legality Social Dilemma: Does Corporate Social Responsibility Impact Consumers' Behaviour? Journal of Policy Modelling, Vol.42. 483-502.

Beer, M., \& Nohria, N. (2000). Breaking the Code of Change. Harvard Business School Press.

Bishop, B. (2006). Theory And Practice Converge: A Proposed Set Of Corporate Communication Principles. Corporate Communications: An International Journal, Vol.11 (3), 214-231.

Chandler, D., \& Werther, W. J. (2014). Strategic Corporate Social Responsibility: Stakeholders, Globalization and Sustainable Value Creation, 3rd edition. Sage.

Cowan, K., \& Guzman, F. (2020). How CSR Reputation, Sustainability Signals, And Country-Of Origin Sustainability Reputations Contribute to Corporate Brand Performance. Journal of Business Research, Vol.117. 683-693.

D.J. Teece. (2009). Dynamic Capabilities and Strategic Management. Oxford University Press.

Ghozali, I. \& Latan, H. (2012). Partial Least Squares: Konsep, Teknik Dan Aplikasi Smartpls 2.0 Untuk Penelitian Empiris. Badan Penerbit Universitas Diponegoro, Semarang.

Gladwell, M. (2000). The Tipping Point: How Little Things Can Make a Big Difference. Little, Brown and Company.

Haryono, S. (2017). Metode SEM untuk penelitian manajemen AMOS LISREL PLS. Luxima Metro Media.

Horngren, Datar, C. T., \& Rajan, S. M. (2011). Cost Accounting A Managerial Emphasis. $14^{\text {th }}$ edition. Prentice Hall.

Kantabutra, S., \& Nuttasorn, K. (2020). Toward A Theory Of Corporate Sustainability: A Theoretical Integration And Exploration. Journal of Cleaner Production, Vol.270. 122292

Kuo, L., \& Chang, B. G. (2021). The Affecting Factors Of Circular Economy Information And Its Impact On Corporate Economic Sustainability-Evidence From China. Sustainable Production and Consumption, Vol.27. 986-997.

Kwon, H.B., \& Lee, J. (2019). Exploring The Differential Impact Of Environmental Sustainability, Operational Efficiency, And Corporate Reputation On Market Valuation In High-Tech Oriented Firms. International Journal of Production Economics, Vol.211. 1-14.

Joshi, A., \& Pal, D. (2015). Likert Scale: Explored and Explained. Journal of Applied Science and Technology,.7(4). 396-403, DOI: 10.9734/BJAST/2015/14975

Lasarov, W., Mai, R., Krause, J. S., Schmidt, U., \& Hoffmann, S. (2021). Too Cold To Be Skeptical: How Ambient Temperature Moderates The Effects Of CSR Communication. Journal of Ecological Economics, 183, 106943.

Leenders, R., \& Gabbay, S. (1999). Corporate Social Capital and Liability. Springer Science.

Littler, K., Aisthorpe, P., Hudson, R., \& Keasey, K. (2000). New Approach to Linking Strategy Formulation And Strategy Implementation: An Example From The UK Banking Sector. International Journal of Information Management, Vo.20(6). 411-428.

Liu, Y., Chen, Y., Ren Y., \& Jin, B. (2021). Impact Mechanism Of Corporate Social Responsibility On 
Sustainable Technological Innovation Performance From The Perspective Of Corporate Social Capital. Journal of Cleaner Production, 308, 127345.

Malhotra, K. N. (2015). Essentials of Marketing Research: A Hands-On Orientation. Pearson.

Morsing, M., \& Spence, L. J. (2019). Corporate Social Responsibility (CSR) Communication And Small And Medium Sized Enterprises: The Governmentality Dilemma Of Explicit And Implicit CSR Communication. Human Relations, 72(12), 1920-1947.

Nita, C. G., \& Stefea, P. (2014). Cost Control For Business Sustainability. Journal of Social and Behavioral Sciences, 124, 307-311.

Pranugrahaning, A., Donovan, J. D., Topple, C., \& Masli, E. K. (2021). Corporate Sustainability Assessments: A Systematic Literature Review And Conceptual Framework. Journal of Cleaner Production, 295, 126385.

Raza, A., Saeed, A., Iqbal, M., Saeed, U., Sadiq, I., \& Faraz, N. (2020). Linking Corporate Social Responsibility To Customer Loyalty Through Co-Creation And Customer Company Identification: Exploring Sequential Mediation Mechanism. Sustainability Journal, $12 . \quad 2525$. doi:10.3390/su12062525

Rahman, M., Serrano, M. A. R., \& Lambkin, M. (2019). Brand Equity and Firm Performance: The Complementary Role of Performance: The Complementary Role Of Corporate Social Responsibility. Journal of Brand Management, 26, 691-704.

Sims, J., \& Seidel, V. P. (2017). Organizations Coupled With Communities: The Strategic Effects On Firms Engaged In Community-Coupled Open Innovation. Journal of Industrial and Corporate Change, 26(4), 647-665.

Sims, R. R. (2003). Ethics and Corporate Social Responsibility: Why Giants Fall. Greenwood Press.

Soytas M., \& Atik, A. (2018). Does Being International Make Companies More Sustainable? Evidence Based On Corporate Sustainability Indices. Central Bank Review, Volume 18, Issue 2, Pages 6168.

Teixeira, G. F. G., \& Junior, O. C. (2019). How to make strategic planning for corporate sustainability? Journal of Cleaner Production. 230, 1421-1431.

Upadhaya, B., Munir, R., Blount, Y., \& Su, S. (2018). Does Organizational Culture Mediate The CSR Strategy Relationship? Evidence From A Developing Country, Nepal. Journal of Business Research, 91, 108-122.

Yamane, T., \& Kaneko, S. (2021). Impact Of Raising Awareness Of Sustainable Development Goals: A Survey Experiment Eliciting Stakeholder Preferences For Corporate Behavior. Journal of Cleaner Production, 285, 125291.

Yamane, T., \& Kaneko, S. (2021). Is The Younger Generation A Driving Force Toward Achieving The Sustainable Development Goals? Survey Experiments. Journal of Cleaner Production, 292, 125932.

Wannags, L. L., \& Gold, S. (2020). Assessing Tensions In Corporate Sustainability Transition: From A Review Of The Literature Towards An Actor-Oriented Management Approach. Journal of Cleaner Production, 264, 121662.

Zhang, Z. (2014). Hierarchical Dynamic Capabilities And Strategic Entrepreneurship In Changing Industrial Environments. Front. Bus. Res. China, 8(3), 388-410.

McKinsey and Company. https://www.mckinsey.com/business-functions/marketing-and-sales/ourinsights/a-global-view-of-how-consumer-behavior-is-changing-amid-covid-19 Consumer sentiment and behavior continue to reflect the uncertainty of the COVID-19 crisis. October 26, 2020

Top 8 challenges of food and beverage industry to watch out for (May 13, 2020). Global Market Insight. https://www.gminsights.com/blogs/challenges-in-food-and-beverage-industry.

Regulasi Tegas Dari Pemerintah Bisa Mendorong Produsen Tinggalkan Plastik Sekali Pakai (February 25, 2021). Greenpeace. https://www.greenpeace.org/indonesia/siaran-pers/44651/regulasi-tegas-daripemerintah-bisa-mendorong-produsen-tinggalkan-plastik-sekali-pakai/

Publik Menagih Tanggung Jawab Produsen Plastik. (February 25, 2021). Greenpeace. https://www.greenpeace.org/indonesia/laporan/44646/publik-menagih-tanggung-jawab-produsen305 
plastik/

Upstream Innovation: a guide to packaging solutions. (2020). Ellen MacArthur Foundation. https://plastics.ellenmacarthurfoundation.org/upstream

2020 Edelman Trust Barometer Special Reports. (2020). Edelman. https://www.edelman.com/trust/2020trust-barometer/special-reports

2021 Edelman Trust Barometer. (2021). Edelman. https://www.edelman.com/trust/2021-trust-barometer Pentingnya Sustainability Report Bagi Semua Tipe Usaha Menurut GRI. (September 7, 2020). https://www.paper.id/blog/finansial-umkm/sustainability-report-adalah/ 